\title{
Identification of Unique or Elevated Levels of Kernel Proteins in Aflatoxin-Resistant Maize Genotypes Through Proteome Analysis
}

\author{
Z.-Y. Chen, R. L. Brown, K. E. Damann, and T. E. Cleveland
}

First and third authors: Department of Plant Pathology and Crop Physiology, Louisiana State University Agricultural Center, Baton Rouge 70803; and second and fourth authors: Southern Regional Research Center, USDA-ARS, New Orleans, LA 70179. Accepted for publication 14 June 2002.

\begin{abstract}
Chen, Z.-Y., Brown, R. L., Damann, K. E., and Cleveland, T. E. 2002. Identification of unique or elevated levels of kernel proteins in aflatoxinresistant maize genotypes through proteome analysis. Phytopathology 92:1084-1094.

Aflatoxins are carcinogens produced by Aspergillus flavus and A. parasiticus during infection of susceptible crops such as maize (Zea mays L.). Resistant maize genotypes have been identified, but the incorporation of resistance into commercial lines has been slow due to the lack of selectable markers. Here we report the identification of potential markers in resistant maize lines using a proteomics approach. Kernel embryo

quantitative and qualitative differences have been identified. Protein spots have been sequenced, and based on peptide sequence homology analysis, are categorized as follows: storage proteins (globulin 1 and globulin 2), late embryogenesis abundant (LEA) proteins related to drought or desiccation (LEA3 and LEA14), water- or osmo-stress related proteins (WSI18 and aldose reductase), and heat-stress related proteins (HSP16.9). Aldose reductase activity measured in resistant and susceptible genotypes before and after infection suggests the importance of constitutive levels of this enzyme to resistance. Results of this study point to a correlation between host resistance and stress tolerance. The putative function of each identified protein is discussed.
\end{abstract} proteins from each of two resistant genotypes have been compared with those from a composite of five susceptible genotypes using large format two-dimensional gel electrophoresis. Through these comparisons, both
Additional keywords: host resistance, resistance-associated proteins.

Infection of maize (Zea mays L.) by Aspergillus flavus and the subsequent accumulation of the toxic and highly carcinogenic secondary metabolites, aflatoxins, is a serious agricultural problem, especially in maize growing under drought conditions (18, 36). Aflatoxin contamination significantly reduces the value of grain as an animal feed and export commodity (34). It also poses health hazards to humans (36) and domestic animals (34).

During the past two decades, maize genotypes with natural preharvest resistance to aflatoxin production have been identified through field screening $(10,43,56)$. Although these discoveries have enhanced the stature of host resistance as a viable strategy for controlling aflatoxin contamination, the poor agronomic quality of these lines render them of little direct commercial value (6), and their levels of resistance may require enhancement to satisfactorily control the problem. Thus, there is a need to continue screening additional germ plasm, as well as to identify resistance traits in existing germ plasm. Recent investigations suggest that kernel resistance to aflatoxin production is a quantitative trait (17, 51). However, the lack of identified selectable markers in these genotypes has slowed the incorporation of resistance into lines with commercially acceptable genetic backgrounds.

While it is known that fungal infection may occur in immature maize kernels, aflatoxin accumulation actually occurs in mature kernels during dry-down (36). This fact facilitated the development of a postharvest laboratory-based rapid screening method, the kernel screening assay (KSA) (8). This widely used procedure has confirmed resistance previously observed in field trials (8),

Corresponding author: R. L. Brown; E-mail address: rbrown@nola.srrc.usda.gov

Publication no. P-2002-0814-01R

This article is in the public domain and not copyrightable. It may be freely reprinted with customary crediting of the source. The American Phytopathological Society, 2002. discovered new potentially resistant lines (7), and demonstrated that resistance to aflatoxin production in most genotypes is likely accomplished through inhibition of A. flavus infection $(8,22)$. Another discovery facilitated by the KSA was the key role of kernel embryo viability in the expression of resistance $(9,12)$. Studies using an $A$. flavus $\beta$-D-glucuronidase (GUS) reporter construct in conjunction with the KSA, further observed that $A$. flavus usually colonizes the embryo tissue and the aleurone layer first, before spreading into the endosperm (8). This suggests that the embryo is the point of entry for A. flavus and possibly a primary point of defense. Other studies have also demonstrated that kernel embryos are colonized before endosperm tissue by aflatoxin-producing fungi $(28,44)$.

Maize kernel protein expression has been implicated in resistance to A. flavus infection/aflatoxin production (6), and side-byside comparisons of resistant with susceptible mature kernel proteins have been performed using one-dimensional (1-D) polyacrylamide gels (14). This comparative method was employed because of the absence of isogenic or near-isogenic maize lines that differ in resistance. Using this method, a constitutively expressed $14-\mathrm{kDa}$ trypsin inhibitor protein (TI) was observed at high levels in the endosperm of resistant lines, but was at low levels or absent in susceptible lines (14). TI demonstrated strong bioactivity in vitro against $A$. flavus and other fungal pathogens (13). In addition to its demonstrated lytic activity against fungal cell walls, TI also was shown to inhibit A. flavus alpha-amylase activity (15). This could hinder fungal ability to utilize endosperm sugars, known precursors for both fungal growth and aflatoxin biosynthesis (59).

In another 1-D study, the constitutive expression of two embryo globulin proteins (GLB1 and GLB2) also was found to be associated with kernel resistance (12). This investigation also demonstrated that while either resistant or susceptible kernels can induce high levels of antifungal proteins upon imbibition or infection, resistant kernels alone have the ability to constitutively express high 
levels of these proteins. This provides a significant advantage to them over susceptible kernels in mounting a defense against $A$. flavus infection and subsequent aflatoxin accumulation (12).

Using 1-D gel to identify other proteins that might correlate with resistance has been limited due to its low resolutions. However, the recent use of immobilized $\mathrm{pH}$ gradients and the latest development in computerized analytical software has dramatically increased the reproducibility, reliability, and accuracy of twodimensional (2-D) polyacrylamide gel electrophoresis (PAGE) (38). Using this methodology, over a dozen proteins were found to be induced in maize subjected to progressive water deficit (39). Also, when 2-D PAGE was employed, a mutant of Arabidopsis thaliana was shown to over-accumulate cytokinins (42).

In the present investigation, 2-D PAGE was employed to compare constitutive protein expression of mature kernels between resistant and susceptible genotypes. Embryo and endosperm proteins were extracted, resolved, and analyzed separately to obtain superior resolution. Results of embryo protein comparisons are presented here; endosperm findings will be reported in the future. Our objective was to identify proteins in two maize genotypes, Mp420 and Mp313E that could correlate with resistance and gain insight into the nature of their involvement. These two genotypes, genetically unrelated but each with proven aflatoxin resistance $(43,58)$, have caught the interest of the seed industry and have been investigated as parents in single cross hybrids involving proprietary germ plasm (57). The identification of potential protein markers in the present study could assist breeders in hastening the development of aflatoxin-resistant commercial maize lines, constructed upon Mp420 or Mp313E resistance traits. Preliminary reports of findings included here have been made (16).

\section{MATERIALS AND METHODS}

Chemicals and materials. Immobilized $\mathrm{pH}$ gradient (IPG) buffer (pH 3.0 to 10.0), Immobiline DryStrip (pH 3.0 to $10.0,18 \mathrm{~cm}$, linear), dithiothreitol (DTT), IPGphor, and a Hoefer-Dalt 2-D electrophoresis system were purchased from Amersham Pharmacia Biotech (Piscataway, NJ). 3-([3-Cholamidopropyl]-dimethylammonio)-1-propane-sulfonate (CHAPS), ammonium persulfate, and $\mathrm{N}, \mathrm{N}, \mathrm{N}^{9}, \mathrm{~N}^{9}$-tetramethyl-ethylenediamine (TEMED) were purchased from Bio-Rad (Hercules, CA). Kernels of commercial maize hybrids Pioneer 3165 (P3165) and Deltapine G4666 (G4666) were obtained from their respective companies; their susceptibility to A. flavus infection/aflatoxin production has been established (22). Kernels of resistant inbred T115 and susceptible inbreds B73 and Mo17 (10) were obtained from the Department of Plant Pathology, University of Illinois, Urbana. Kernels of susceptible inbred Va35 and resistant inbreds (Mp420 and Mp313E) (43) were from the USDA-ARS, Corn Host Plant Resistance Research Unit, Mississippi State. Kernels of resistant breeding population GTMAS:gk were obtained from the USDA-ARS, Insect Biology and Population Management Research Laboratory, Tifton, GA.

Protein extraction. Kernels (20 g) from each genotype were dissected into embryo and endosperm after being soaked in water overnight at $0^{\circ} \mathrm{C}$. These conditions were employed to facilitate the separation without protein induction (confirmed using western blot analysis). Embryo proteins were extracted with an extraction buffer $(0.25 \mathrm{M} \mathrm{NaCl}, 50 \mathrm{mM}$ Tris- $\mathrm{HCl}, \mathrm{pH} 8.0,14 \mathrm{mM} \beta$-mercaptoethanol) $(4 \mathrm{ml} / \mathrm{g})$ for $10 \mathrm{~min}$ on ice using a mortar and pestle, centrifuged $\left(20 \mathrm{~min}\right.$ at $35,000 \times g$ at $\left.4^{\circ} \mathrm{C}\right)$, and the supernatant was precipitated with five volumes of cold $\left(-20^{\circ} \mathrm{C}\right)$ acetone overnight. Proteins were recovered by centrifugation (30 $\mathrm{min}$ at $35,000 \times \mathrm{g}$ at $4{ }^{\circ} \mathrm{C}$ ) and dried under vacuum before resolubilizing in lysis buffer (9.5 M urea, 2\% CHAPS, 1\% DTT, 0.8\% wt/vol IPG buffer, $\mathrm{pH} 3$ to $10,0.04 \%$ Pefabloc proteinase inhibitor) at a final concentration of $2 \mu \mathrm{g} / \mu \mathrm{l}$. The resultant mixture was centrifuged for $30 \mathrm{~min}$ at $35,000 \times g\left(15^{\circ} \mathrm{C}\right)$, to prepare the supernatant for loading on a rehydrated IPG gel strip, or alternatively, for storing at $-78^{\circ} \mathrm{C}$ until use. This experiment was performed twice, and each sample was run in triplicates.

First-dimension gel electrophoresis. Immobiline DryStrip gels ( $\mathrm{pH} 3$ to 10) were rehydrated overnight in $350 \mu$ l of rehydration solution (8 M urea, 1\% CHAPS, $20 \mathrm{mM}$ DTT, 0.2\% wt/vol Pharmalyte 3-10 carrier ampholytes) at $20^{\circ} \mathrm{C}(21)$. Fifty (analytical) to $700 \mu \mathrm{g}$ (preparative) of the above supernatant was applied to either or both of the lateral wells at either end of the strip holders. Isoelectric focusing (IEF) was performed at $20^{\circ} \mathrm{C}$ for $6 \mathrm{~h}$ under the following conditions: $1 \mathrm{~h}$ at $500 \mathrm{~V}, 1 \mathrm{~h}$ at $1,000 \mathrm{~V}$, and $4 \mathrm{~h}$ at 8,000 V. Current was limited to $0.05 \mathrm{~mA}$ per IPG gel strip. The focused strips were equilibrated immediately for $15 \mathrm{~min}$ in $10 \mathrm{ml}$ of sodium dodecyl sulfate (SDS) equilibration buffer $(50 \mathrm{mM}$ Tris$\mathrm{HCl}$ buffer $\mathrm{pH} 8.8,6 \mathrm{M}$ urea, 30\% wt/vol glycerol, $2 \% \mathrm{wt} / \mathrm{vol}$ SDS, and 1\% wt/vol DTT) (21). After equilibration, IPG gel strips were embedded in a $1 \%$ agarose solution at the top of the 2-D gel.

Second-dimension gel electrophoresis, staining and gel analysis. SDS-PAGE was performed in $13.5 \%$ polyacrylamide gels $(235 \times 190 \times 1.5 \mathrm{~mm}$, width $\times$ length $\times$ thickness $)$ at $10^{\circ} \mathrm{C}$ at a constant voltage of $120 \mathrm{~V}$ for $2,000 \mathrm{~V}$ h. Protein spots in analytical gels were stained automatically with Silver Stain Kit (Genomic Solutions, Chelmsford, MA) using an Investigator Gel Processor (Genomic Solutions). Preparative gels were stained with Coomassie Brilliant Blue R 250 and all stained gels were scanned using a UMAX PowerLook II scanner (UMAX data systems, Taiwan), and analyzed using the BioImage software package (BioImage, Ann Arbor, MI) on a Sun Ultra 5 workstation. Only the reproducible spots were used for comparison (over $90 \%$ of all protein spots detected on 2-D gels for a given genotype are reproduced [or matched]). In gel-to-gel comparisons, spot integrated intensity (I. I.) was normalized using the sum of the I. I. of all spots in a gel divided by the sum of the I. I. of all spots in the reference gel to minimize loading and staining variations between gels. 2-D gels from resistant genotypes Mp420 or Mp313E were compared to composite gels generated from five susceptible maize genotypes to obtain protein spots that are only present or at least fivefold up-regulated in the resistant lines compared to susceptible lines.

Peptide sequencing. Protein spots from two to five Coomassie Brilliant Blue R 250-stained prep 2-D gels were excised with a combined total protein amount ranging from 10 to 20 pmol. These protein spots were subjected to in-gel trypsin digestion and analyzed by electrospray ionization tandem mass spectrometry (ESIMS/MS) (PE SCIEX API 3000 equipped with a nanospray source from Protana, Applied Biosystems, Foster City, CA) to obtain peptide sequence information at the Protein Chemistry Core Facility, Baylor College of Medicine (Houston, TX). When peptide sequences could not be obtained unambiguously by using ESIMS/MS, Edman degradation was performed using an Applied Biosystems Procise cLC sequencer to obtain sequence information for protein identification.

Database sequence homology analysis. Peptide sequence homology searches against known proteins or translated open reading frames of expressed sequence tags (ESTs) in databases at the National Center for Biotechnology Information (NCBI) and SWISSProt were performed using basic local alignment search tool (BLAST) (1).

Aflatoxin production versus aldose reductase activity. Further experiments were performed to investigate the existence of an association between aldose reductase and kernel aflatoxin resistance. Kernels (120 per genotype) of four resistant (Mp420, Mp313E, GT-MAS:gk, and T115) and three susceptible genotypes (B73, G4666, and P3165) were surface-sterilized as described (9). Forty kernels from each genotype were ground in an analytical mill with liquid $\mathrm{N}_{2}$ and extracted in the above extraction buffer as described in a previous study (14). The crude extract was used for an aldose reductase activity assay (below). The remaining 80 kernels from each genotype were inoculated with an A. flavus 
conidia suspension $\left(5 \times 10^{6}\right.$ conidia per $\left.\mathrm{ml}\right)$ and incubated at $31^{\circ} \mathrm{C}$ under $100 \%$ humidity for 7 days as previously described (9). At the end of incubation, 40 kernels were ground for aldose reductase activity assay, and the remaining 40 kernels (four kernels per replicate) were bagged, dried, and used for aflatoxin determination using the method of Brown et al. (9). The experiment was conducted twice.

Aldose reductase activity was photometrically determined by measuring the decrease in the concentration of reduced nicotinamide adenine dinucleotide phosphate (NADPH) at $340 \mathrm{~nm}$ for $5 \mathrm{~min}$ at room temperature according to Kawasaki et al. (27). Assay mixtures $(500 \mu \mathrm{l})$ contained $100 \mathrm{mM}$ sodium phosphate buffer, pH 6.9, $0.15 \mathrm{mM}$ NADPH and $10 \mathrm{mM}$ DL-glyceraldehyde as substrate. The reaction was initiated by adding the enzyme. The protein concentrations were determined using the Bio-Rad protein assay kit according to Bradford (5).

Statistical analysis. All data were analyzed using the analysis of variance procedure of the Statistical Analysis System (SAS Institute, Cary, NC). Aflatoxin data were log-transformed prior to analysis to equalize variances. Means were separated by Duncan's multiple range test $(P \leq 0.05)$.

\section{RESULTS}

Identification of unique or up-regulated protein spots. Protein spots from each gel were first identified and quantified using the BioImage 2-D gel analysis software. A typical 2-D gel of embryo proteins contained 1,200 to 1,500 spots when stained with silver. The majority was concentrated in the $\mathrm{pH} 4$ to 8 region with a molecular mass ranging from $24 \mathrm{kDa}$ to $80 \mathrm{kDa}$ (data not shown). The unique and up-regulated protein spots in the aflatoxin-resistant genotype Mp420 were identified through spot matching between the gels from Mp420 and the composite gel generated from five susceptible genotypes. The unique spots in Mp420 with I.I greater than 1.5 are listed in Table 1. Spots 1423 and 875 from Mp420 were missing in all five susceptible genotypes, and the remaining protein spots were missing in four of five susceptible genotypes. The quantitative differences between Mp420 and the five susceptible genotypes also were determined among the common spots. The protein spots whose level of expression were fivefold or higher in Mp420 compared with all or four of five susceptible genotypes, such as 1133 and 1724, are summarized in Table 1. The subsections of representative gels from each genotype showing some of the unique or up-regulated protein spots are presented in Figure 1.
Mp313E contains most of the unique and up-regulated proteins identified in Mp420. The major qualitative difference between Mp313E and Mp420 is that Mp313E contained a unique region of protein spots with molecular mass of 24.6 to $27.3 \mathrm{kDa}$ and isoelectric point (pI) ranging from 5.2 to 5.4. These spots (1508, 1538,1562 , and 1568), collectively called 1508 s, were missing in the embryos of all susceptible genotypes (Fig. 2, Table 2). However, protein spot 1544 next to 1508 s, was observed in one of the susceptible genotypes (P3165) (Fig. 1B, indicated with an open arrow). Four protein spots whose level of expression was found up-regulated fivefold or more in Mp313E compared to all susceptible genotypes were also identified (Table 2).

Another major change observed in comparing 2-D gels of different maize genotypes is the position shift of several protein spots. One such example is spot 1133, which appears in position four in Mp420 and position one in Mp313E (1136) (Fig. 3). In all susceptible genotypes, this protein (as confirmed by sequence analysis) assumes positions two and/or three except for B73, in which this protein appears in position four (Fig. 3).

Protein sequencing and database query. Eleven protein spots identified in the above comparison of embryo proteins between resistant and susceptible genotypes were selected for peptide sequencing using ESI-MS/MS and conventional Edman degradation when MS failed to yield any usable sequence data. Two to nine peptides were sequenced from each spot for positive identification of the protein. The peptide sequences obtained for each spot and their homology identified through database searches are summarized in Table 3. All spots had significant sequence homology to known proteins except 1300, in which only one of its four peptide sequences showed low homology to an anionic peroxidase $\mathrm{H}$ from maize (GenBank Accession No. AAC79953) (Table 3).

The peptide sequence of spot 1508 s is identical to maize globulin 1-L (GLB1-L) (30), a major storage protein in maize embryos with a calculated molecular mass of $66.2 \mathrm{kDa}$ (Fig. 4A). Peptide sequences of spot 1391 are identical to those obtained from peptides one and four of spot 1406 (Table 3). These two peptides, along with peptide three of spot 1406, showed $97 \%$ homology (with only one mismatch) to globulin 2 (GLB2) of maize (52), another major embryo storage protein with a calculated molecular mass of $49.9 \mathrm{kDa}$ (Fig. 4B). The other peptide (peptide 2) (DGAQQTGSYVAQTAE) showed significant homology (73\%) to a rice water-stress inducible protein (WSI18, GenBank Accession No. BAA05537) (47), indicating that contained within spot 1406 are two different proteins.

TABLE 1. Summary of unique and up-regulated spots in Mp420 embryo compared to five susceptible maize genotypes

\begin{tabular}{|c|c|c|c|c|c|}
\hline & Spot number & $\begin{array}{l}\text { Integrated intensity of protein } \\
\text { spots }(\text { I.I })^{\mathrm{v}}\end{array}$ & Area of protein spot in $\mathrm{mm}^{2 \mathrm{w}}$ & Isoelectric point $(\mathrm{pI})^{\mathrm{w}}$ & $\begin{array}{l}\text { Molecular weight } \\
(\mathrm{MW})^{\mathrm{w}}\end{array}$ \\
\hline \multirow[t]{9}{*}{ Unique spots } & $1423^{x y}$ & $4.04 \pm 0.96$ & 4.43 & 9.3 & 24344.0 \\
\hline & $875^{\mathrm{x}}$ & $2.95 \pm 0.44$ & 3.51 & 6.8 & 47256.0 \\
\hline & $1406^{\mathrm{yz}}$ & $5.27 \pm 1.43$ & 5.68 & 9.7 & 24946.2 \\
\hline & $1391^{\mathrm{yz}}$ & $8.61 \pm 1.75$ & 9.10 & 8.4 & 25133.9 \\
\hline & $1300^{\mathrm{yz}}$ & $3.73 \pm 1.04$ & 3.92 & 5.3 & 27975.6 \\
\hline & $1175^{\mathrm{z}}$ & $9.12 \pm 2.31$ & 8.42 & 5.6 & 33913.9 \\
\hline & $772^{z}$ & $3.34 \pm 0.61$ & 2.96 & 6.7 & 51395.8 \\
\hline & $492^{z}$ & $3.24 \pm 0.73$ & 3.63 & 5.3 & 60948.9 \\
\hline & $574^{z}$ & $2.83 \pm 0.49$ & 3.18 & 5.2 & 58356.3 \\
\hline \multirow[t]{5}{*}{ Fivefold up-regulated spots } & $1133^{y}$ & $11.39 \pm 1.91$ & 8.23 & 7.1 & 36241.3 \\
\hline & $1724^{y}$ & $16.67 \pm 3.20$ & 12.63 & 5.8 & 14943.5 \\
\hline & $1868^{y}$ & $8.59 \pm 0.53$ & 19.66 & 5.2 & 14208.2 \\
\hline & 311 & $6.02 \pm 0.50$ & 5.53 & 7.6 & 68820.7 \\
\hline & 947 & $1.88 \pm 0.32$ & 2.91 & 4.8 & 44572.0 \\
\hline
\end{tabular}

\footnotetext{
${ }^{v}$ I.I, which have the most variations, the values presented here are means \pm standard error.

${ }^{\mathrm{w}}$ The values for area, pI, and MW are the means of the same spot obtained from replicated gels in two studies.

x Spots are missing in all susceptible genotypes.

y Spots were selected for amino acid sequence analysis.

${ }^{\mathrm{z}}$ Spots are missing in four out of five susceptible genotypes.
} 

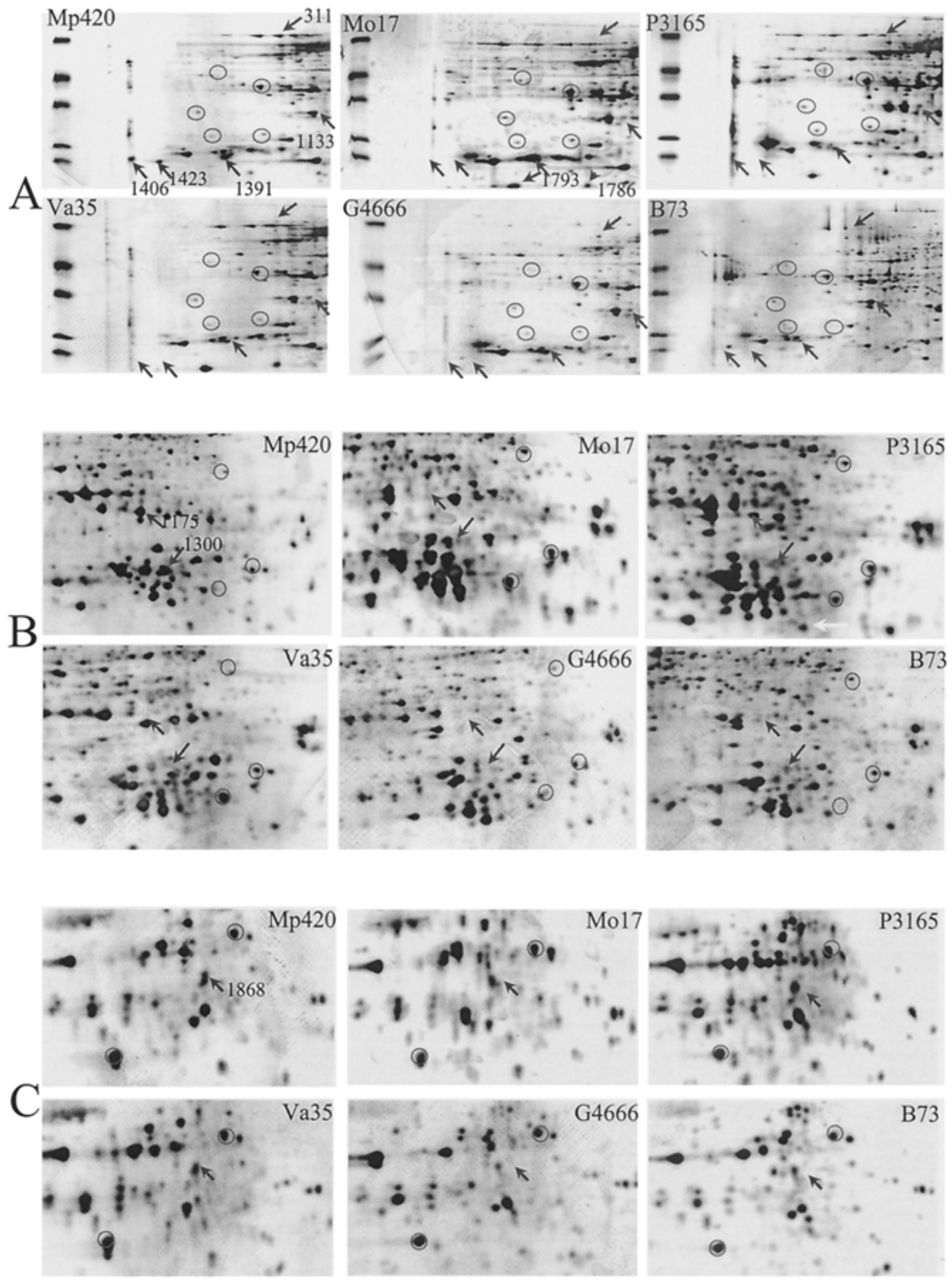

Fig. 1. Comparisons of embryo proteins between resistant (Mp420) and susceptible (B73, Mo17, Va35, G4666, P3165) maize genotypes separated through twodimensional (2-D) gel electrophoresis. A, B, and C are three subsections of 2-D gels, corresponding to molecular weight (MW) from 80,000 to 22,000 (top to bottom) and isoelectric point (pI) from 10.0 to 7.0 (left to right), MW from 45,000 to 22,000 and pI from 7.0 to 4.0, and MW from 22,000 to 6,500 and pI from 7.5 to 3.5, respectively. Circles indicate the common spots used as anchors. Solid arrows indicate unique or up-regulated spots in Mp420. B, The open arrow in P3165 indicates the spot is matched to a protein (1544) in Mp313E. 

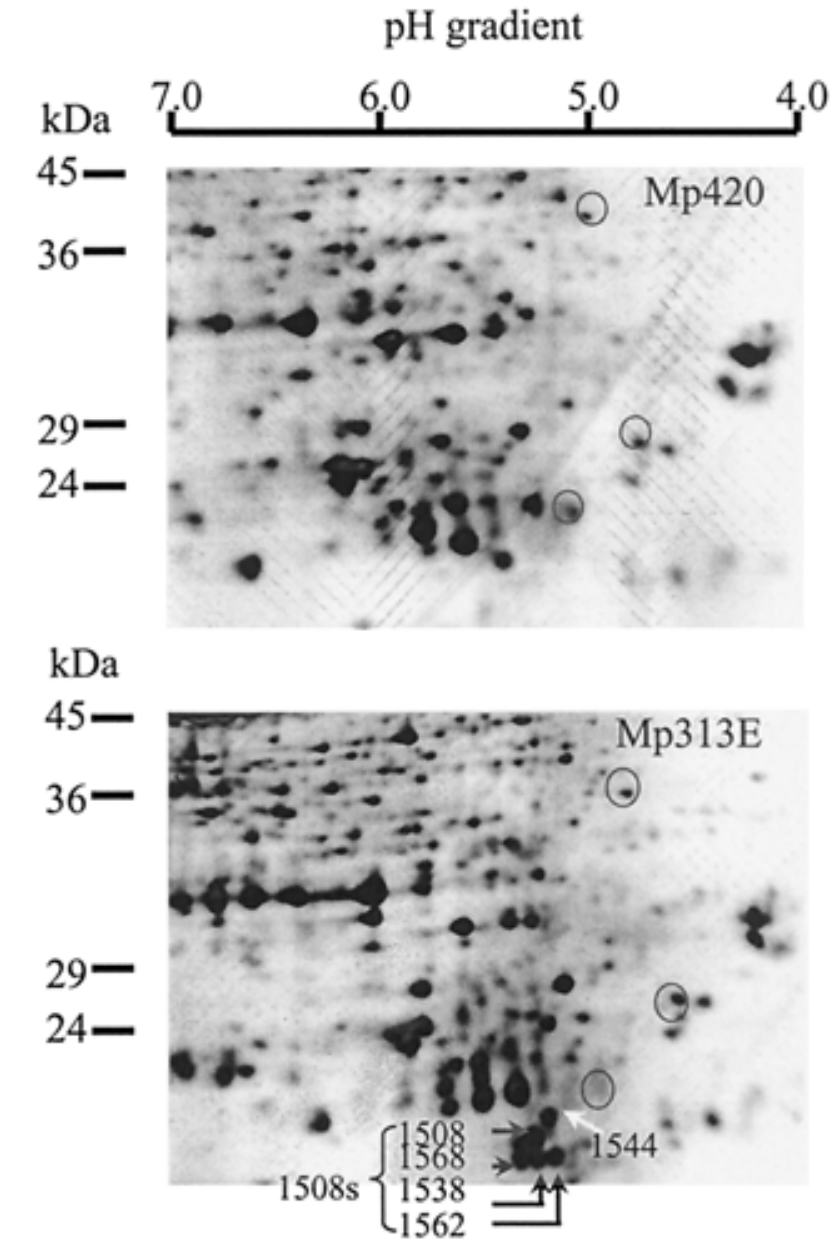

Fig. 2. Subsection of a two-dimensional polyacrylamide gel electrophoresis gel showing some of the unique protein spots (1508s) in the embryo of resistant genotype Mp313E compared to Mp420. The range of isoelectric point (pI) and molecular mass in $\mathrm{kDa}$ was indicated on the top and the left side of gels, respectively. Circles represent the common spots used as anchors. Spots belonging to $1508 \mathrm{~s}$ are indicated with solid arrows. The open arrow indicates spot 1544 is present in one of the susceptible genotypes, P3165.
Spot 1423 was shown to be a maize group three late embryogenesis abundant protein (LEA3) (55) based on its peptide sequence homology. Two other protein spots (1793 and 1786) with lower molecular weight (MW) and $\mathrm{pI}$ from a susceptible genotype (Mo17) also were found to be LEA3 proteins (Table 3, Fig. 5A). The calculated MW and pI of maize LEA3 is 22,758 and 8.80, respectively. The significantly higher pI and MW of spot 1423 compared to the other two indicates that they may be encoded by two homologous genes or by one gene with different posttranslational modifications.

Peptide sequence analysis indicated that spot 1868 contained more than one protein. Peptides two, three, and six to eight (Table 3) showed high homology to group four late embryogenesis abundant protein (LEA14) from cotton (GenBank Accession No. P46518; 70.5\% identity), a desiccation related protein from Arabidopsis thaliana (GenBank Accession No. AAC62908; 63.6\% identity), and a desiccation protectant protein from soybean (GenBank Accession No. P46519; 61.4\% identity) (Fig. 5B). These peptide sequences also are highly homologous to the deduced amino acid sequences of several maize ESTs, such as AW331170 (68.2\%) and AW566229 (72.7\%) (Fig. 5B). No homology was found for sequences obtained from peptides one, four, five, and nine of spot 1868 (Table 3).

The peptide sequence of spot 1724 is highly homologous to a heat shock protein (HSP) 16.9 from pearl millet and rice (both $84.8 \%$ identity) $(11,50)$ and a HSP 17.2 (GenBank Accession No. S23212; 90.9\% identity) from maize (Fig. 6). A sequence homology search of maize ESTs using BLAST found five more HSPs encoding sequences. The peptide sequence of spot 1724 shows a complete match to the deduced amino acid sequences of three ESTs (AW258080, BE056217, and BE123268), and is highly homologous (90.9\% identity) to that of the other two ESTs (AW067565 and BE639130) (Fig. 6).

Spots 1133 from Mp420 and 1136 from Mp313E, although different from each other in peptide sequence (Table 3 ), showed significant sequence homology (about $80 \%$ identity) to an NADPH-dependent aldose reductase (ALD) from barley (2), wild oat (32), and the merged amino acid sequences deduced from two maize ESTs (Fig. 7). This indicates the presence of multigenes to encode aldose reductase in maize. The peptide sequence analysis of spot 1136 also shows that at least one of the amino acid residues was posttranslationally modified (Table 3 , indicated with an $\mathrm{X}$ ), suggesting it may contribute to the observed position shift in 2-D gels (Fig. 3). $X$ residue is not one of the

TABLE 2. Summary of unique and up-regulated spots in Mp313E embryo compared to five susceptible maize genotypes

\begin{tabular}{|c|c|c|c|c|c|}
\hline & Spot number & $\begin{array}{l}\text { Integrated intensity of protein } \\
\text { spots. (I.I) }{ }^{\mathrm{u}}\end{array}$ & Area of protein spot in $\mathrm{mm}^{2 \mathrm{v}}$ & Isoelectric point $(\mathrm{pI})^{\mathrm{v}}$ & $\begin{array}{l}\text { Molecular weight } \\
(\mathrm{MW})^{\mathrm{v}}\end{array}$ \\
\hline Unique spots & $\begin{array}{c}1482^{w x} \\
1538^{w x y} \\
1562^{w x y} \\
1568^{w x y} \\
1820^{w} \\
1845^{w} \\
676^{z} \\
947^{z} \\
1166^{x z} \\
1467^{z} \\
1544^{z}\end{array}$ & $\begin{array}{l}2.90 \pm 0.41 \\
2.02 \pm 0.45 \\
4.02 \pm 0.63 \\
3.12 \pm 0.88 \\
2.68 \pm 0.55 \\
3.55 \pm 0.49 \\
8.21 \pm 1.68 \\
2.00 \pm 0.35 \\
2.18 \pm 0.52 \\
4.71 \pm 0.76 \\
7.92 \pm 2.03\end{array}$ & $\begin{array}{l}7.82 \\
2.86 \\
5.11 \\
4.47 \\
6.59 \\
6.13 \\
9.27 \\
3.52 \\
3.46 \\
7.01 \\
8.52\end{array}$ & $\begin{array}{l}8.7 \\
5.4 \\
5.2 \\
5.4 \\
5.1 \\
5.0 \\
7.2 \\
6.5 \\
8.0 \\
6.8 \\
5.3\end{array}$ & $\begin{array}{l}25753.2 \\
25763.3 \\
25201.6 \\
24676.1 \\
18270.7 \\
17803.6 \\
54672.3 \\
47766.8 \\
39266.5 \\
28160.9 \\
26202.8\end{array}$ \\
\hline Fivefold up-regulated spots & $\begin{array}{c}885 \\
355 \\
1136^{x} \\
1529^{x}\end{array}$ & $\begin{array}{l}8.39 \pm 1.93 \\
1.71 \pm 0.21 \\
9.36 \pm 1.38 \\
4.69 \pm 0.39\end{array}$ & $\begin{array}{r}11.33 \\
4.10 \\
10.32 \\
6.54\end{array}$ & $\begin{array}{l}8.2 \\
7.5 \\
8.0 \\
9.4\end{array}$ & $\begin{array}{l}49786.1 \\
66773.7 \\
39266.0 \\
23165.0\end{array}$ \\
\hline
\end{tabular}

u I.I, which have the most variations, the values presented here are means \pm standard error.

$\checkmark$ The values for area, pI, and MW are the means of the same spot obtained from replicated gels in two studies.

${ }^{\text {w }}$ Spots are missing in all susceptible genotypes.

x Spots were selected for amino acid sequence analysis.

y Spots $1508,1538,1562$, and 1568 are also collectively called 1508 s.

${ }^{\mathrm{z}}$ Spots are missing in four out of five susceptible genotypes. 
known common amino acid residues based on mass spectrum (data not shown).

Aflatoxin production versus aldose reductase activity. It was found that susceptible genotypes G4666 and P3165 initially contained lower levels of aldose reductase than did resistant genotypes Mp420, T115, and GT-MAS:gk (Table 4). However, after fungal infection, aldose reductase levels in these lines were higher than in resistant lines. B73 and Mp313E were two exceptions. B73 expressed preinfection levels comparable to Mp420, and postinfection levels significantly lower than both G4666 and P3165. The level of ALD activity in Mp313E was comparable to G4666 both before and after infection (Table 4).

Aflatoxin production in susceptible lines, G4666 and P3165, was significantly higher than in resistant lines, Mp420, T115, and GT-MAS:gk (Table 4). In aflatoxin accumulation, again B73 and Mp313E displayed intermediate responses.

\section{DISCUSSION}

Increased temperatures and drought, which often occur together, are major factors associated with aflatoxin contamination of maize kernels (36). Field studies have found, in most years, that irrigation to reduce water-stress also reduced aflatoxin contamination $(26,37)$. Other studies $(36,54)$ have found that drought-stress imposed during grain filling reduces dry matter accumulation in kernels. This often leads to cracks in the seed and provides an easy entry site to insects and fungi. Therefore, it is likely that droughtstress contributes to the compromise of host plant defense systems (26), thereby increasing insect activity and A. flavus colonization of kernels.

The present study, for the first time, used a proteomics approach to identify variations in maize kernel protein expression between aflatoxin-resistant and aflatoxin-susceptible genotypes. The reason for using this approach was to take advantage of the increased reproducibility, reliability, and accuracy that 2-D PAGE offers over 1-D gel electrophoresis. The two genotypes used in this study, Mp313E and Mp420, are resistant to A. flavus infection and aflatoxin production and are viewed as excellent sources of resistance by the seed industry. The authors' initial intention was not to identify stress-related proteins in these lines, however, the unique or up-regulated proteins identified on 2-D gels of these genotypes corresponded to proteins reported to be up-regulated by or related
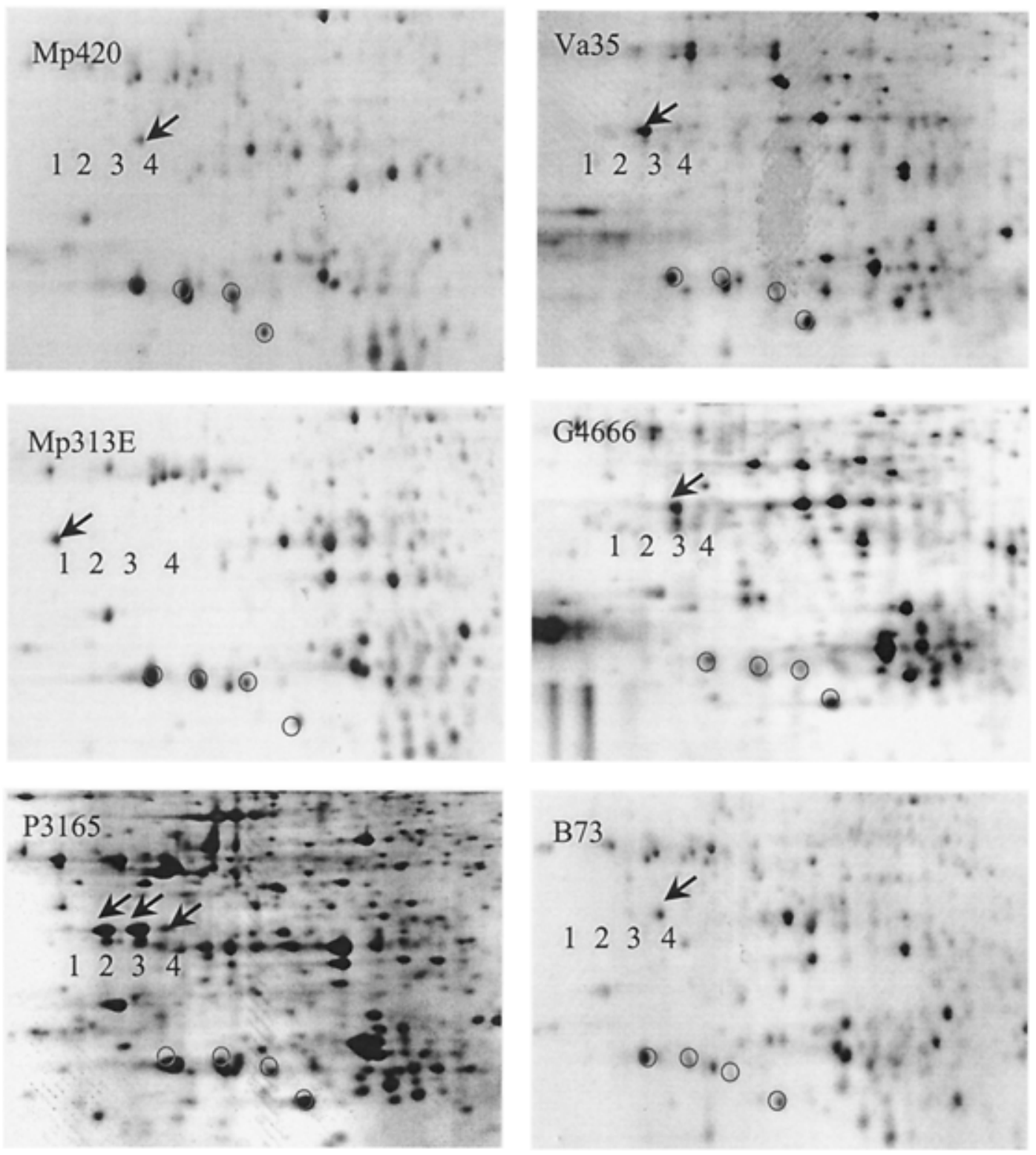

Fig. 3. Position shifts of spot 1133 in Mp420 and other genotypes. "1 23 4" represents four possible positions the spot corresponding to 1133 in Mp420 may take in each genotype (indicated with arrows). Circles indicate the common spots used as anchors. 
to water- or drought-stress $(29,40,41,47,48,60)$. These identified proteins include globulins (GLBs), late embryogenesis abundant proteins (LEAs), a water stress-inducible protein (WSI), aldose reductase (ALD), and heat shock proteins (HSP). In light of the relationship between drought and aflatoxin accumulation, these findings may indicate a correlation between a kernel's resistance to A. flavus infection/aflatoxin production and its stress tolerance. Possession of unique or higher levels of the identified proteins, constitutively expressed, may put resistant lines in an advantageous position over susceptible ones in the ability to synthesize proteins and defend against pathogens under stress conditions. Since the kernels used in this study were from different seed lots (growth locations and/or growing seasons), the effect of seed lot on the expression of the observed protein differences between the resistant and susceptible genotypes was examined. Variation in the expression of the same protein spot among different seed lots of a given genotype was similar to that observed between replicate 2-D gels with identical protein samples (data not shown). This variation, usually less than twofold, does not affect our original observations (based on a minimum of fivefold differences).

In the present investigation, several unique proteins with molecular mass between 24 and $27 \mathrm{kDa}$ found in Mp313E were identified as GLB1s. The peptide sequences obtained from these spots were all aligned to the $\mathrm{C}$ terminus of GLB1, indicating that this singlegene encoded protein may be processed differently in different genotypes at its $\mathrm{N}$ terminus after its initial synthesis (30). Also, two distinct protein spots (1406 and 1391) with molecular mass of approximately $25 \mathrm{kDa}$ were found to contain amino acid sequences identical to GLB2, suggesting these may be derived from posttranslational proteolysis of the N-terminus of GLB2 as well (46).

In addition to globulins, a couple of LEA proteins were also found either unique (1423) or up-regulated (1868) in resistant maize line Mp420. One of the unique features about GLBs and LEA3 is that they are highly hydrophilic, containing high levels of glycine (>6\%) (20), and the expression of GLB1 and LEA3 has been reported to be stress-responsive and abscisic acid (ABA)-dependant (48). Increased tolerance to water and salt stress was also observed in rice transformed with a LEA protein from barley (60). It is interesting to note that GLB1 accumulates early in the maturation phase, while LEA3 accumulates later in embryogenesis, coinciding with the onset of dehydration (48) and the outbreak of aflatoxin production in infected kernels (36).

A protein homologous to rice WSI18 (47) was found in Mp420, and is specifically induced in rice by short-term water stress. The

TABLE 3. Summary of peptide sequences obtained through electrospray ionization tandem mass spectrometry (ESI/MS) and Edman degradation

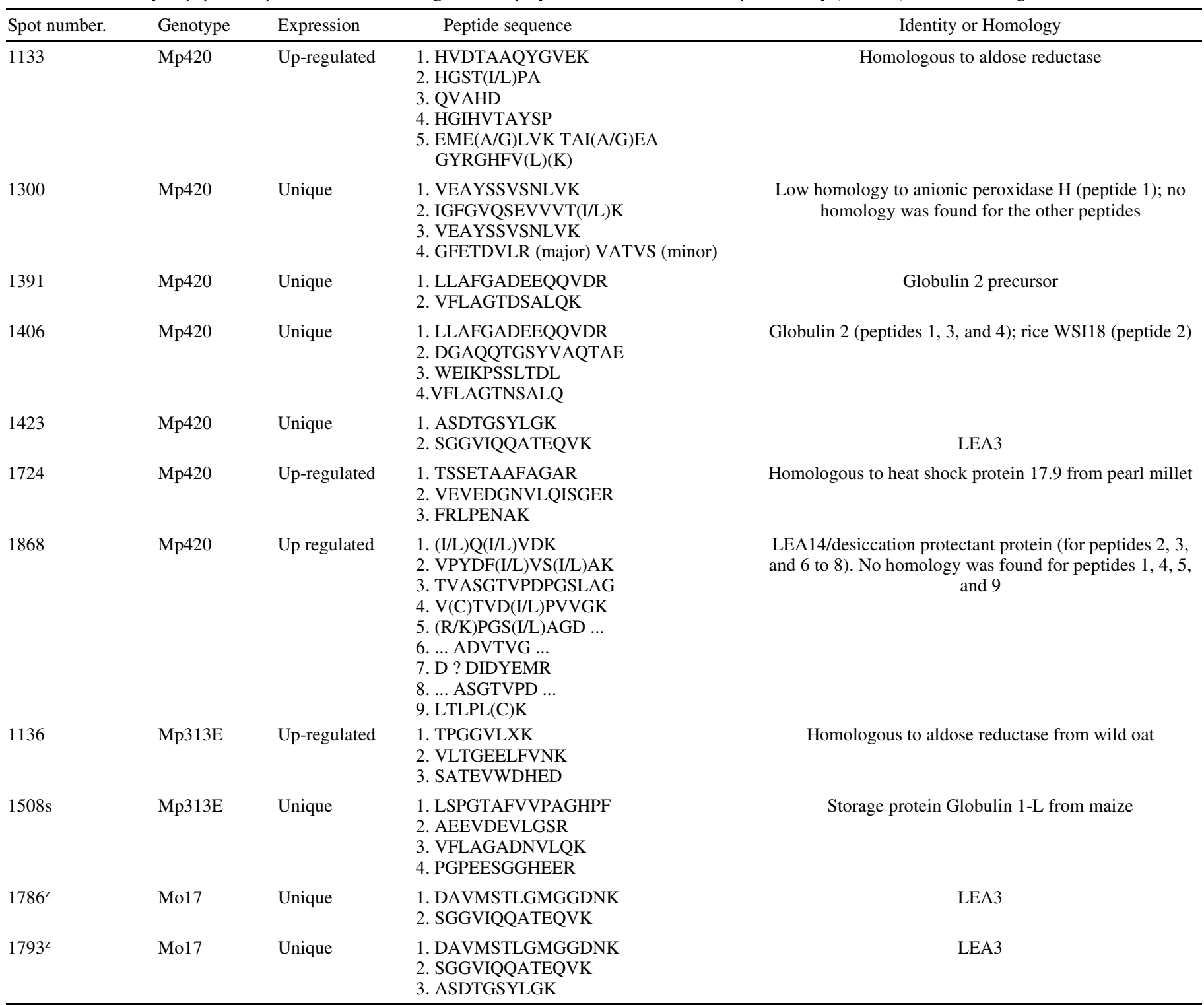

${ }^{\mathrm{z}}$ Expression of spots 1786 (Isoelectric point (pI) 7.6, Molecular weight (MW) 22,607) and 1793 (pI 8.6, MW 22,107) was classified as unique in Mo17 due to their position shifts though the same LEA3 is also present in other genotypes, such as Mp420 spot 1423 (pI 9.3, MW 24,433). 
expression of WSI18 genes was found to increase when rice seedlings were subjected to chilling (47). Also, a conserved amino acid sequence common to LEA-group genes in the $\mathrm{N}$-terminal region was revealed in WSI18 (47).

Aside from heat stress, HSPs also are induced by other stresses such as cold, drought, or salinity $(29,41)$. Other studies have demonstrated that HSPs possess in vitro molecular chaperone activity $(24,25)$, enhance thermotolerance in recombinant Escherichia coli cells $(45,61)$, and may play a generally protective role in desiccation tolerance (53).

ALD, whose up-regulated expression was observed in both MP313E and Mp420, is reportedly involved in the synthesis of an osmolyte sorbitol (2). Its expression in barley embryo temporally correlated with the acquisition of desiccation tolerance (40), a role for ALD in osmoregulation (2), and in the induction and mainten- ance of freezing tolerance by ABA (31) has been suggested. Recently, it was also found that an NADPH-dependent alfalfa ALD protects transgenic tobacco plants against lipid peroxidation under chemical (paraquat and heavy metal) and drought stresses (35).

To explore the relationship between ALD expression and kernel aflatoxin accumulation and establish a sense of correlation, resistant (including the addition of T115 and GT-MAS:gk) and susceptible lines were further compared. Variation in levels of ALD activity between resistant lines (Mp420, T115, and GT-MAS:gk) and susceptible (G4666 and P3165) lines, both before and after infection, was observed. B73, normally considered a susceptible genotype, responded atypically in both aflatoxin accumulation and ALD activity. This is not unprecedented since B73 often displays intermediate susceptibility to aflatoxin production in both field and lab studies $(8,10)$. Resistant genotype Mp313E, however,

A

\begin{tabular}{|c|c|c|c|c|c|c|c|}
\hline Pre-GLB1 & E-SSEEQEEVGQGYH & TIRARLSPGTAFVVP & AGHPFVAVASRDSNL & QIVCFEVHADRNEKV & FLAGADNVLQKLDRV & AKALSFASKAEEVDE & 494 \\
\hline GLB1-I & EESSEEQEEAGQGYH & TIRARLSPGTAFVVP & AGHPFVAVASRDSNL, & QIVCFEVHADRNEKV & FLAGADNVLQRLDRV & AKALSFASKAEEVDE & 492 \\
\hline GIBI-S & E-SSEEQEEVGQGYH & TIRARLSPGTAFVVP & AGHPFVAVASRDSNL & QIVCFEVHADRNEKV & FLAGADNVLQKLDRV & AKALSFASKAEEVDE & 461 \\
\hline$\# 1508 \mathrm{~s}$ & 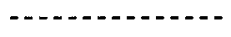 & ---LSPGTAFVVP & AGHPP - - & $-------------V$ & FLAGADNVLQK - - - - & $------A B B V D E$ & 33 \\
\hline Pre-GLB1 & VLGSRREKGFLPGI & SSGGHEEREQEEEER & EERHGGRGER & EERE & - EREGRHGRG & EEVAETLLRMVTARM & 573 \\
\hline GLB1-I & VLGSRREKGFLPGPE & ESGGHFEREQEEEER & EERHGGRGERERHGR & EEREKEEEREGRHGG & REEREEEERHGRGRR & EEVAETLMRMVTARM & 582 \\
\hline GLB1 - S & VLGSRREKGELPGPK & ESGGHERREQEEEER & EERHGGRGERERHGR & EEREKEEE- - - - - & - - - -EREGRHGRGRR & EEVAETLLRMVTARM & 540 \\
\hline$\# 15088$ & VLGSR----- PGPE & ESGGHERR----- & ------ & ------ & ------ & ----- & 50 \\
\hline
\end{tabular}

B

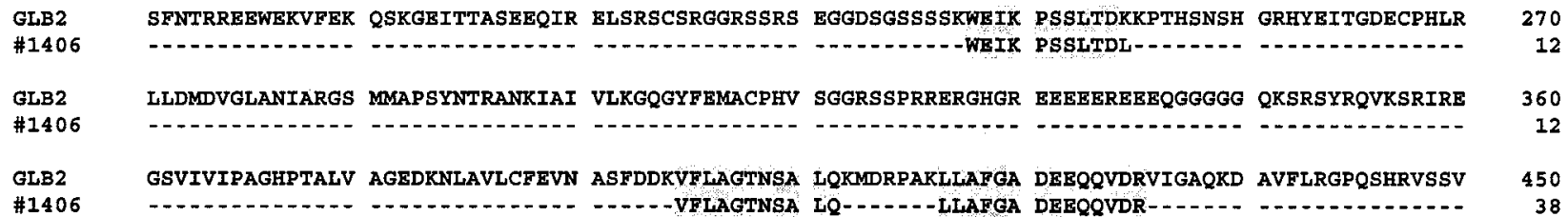

Fig. 4. Amino acid sequence alignment of $\mathbf{A}$, maize globulin 1 with peptide sequences from spot $1508 \mathrm{~s}$ and $\mathbf{B}$, maize globulin 2 protein with pepetide sequences obtained from spot 1406. Pre-GLB1, maize globulin 1-S (GLB1-S, S21825) allele precursor (P15590) (3); GLB1-L, maize vicilin-like storage protein globulin 1-L (B53234) (4); GLB2, maize globulin 2 protein (228310) (52). The conserved amino acid residues are highlighted.

A

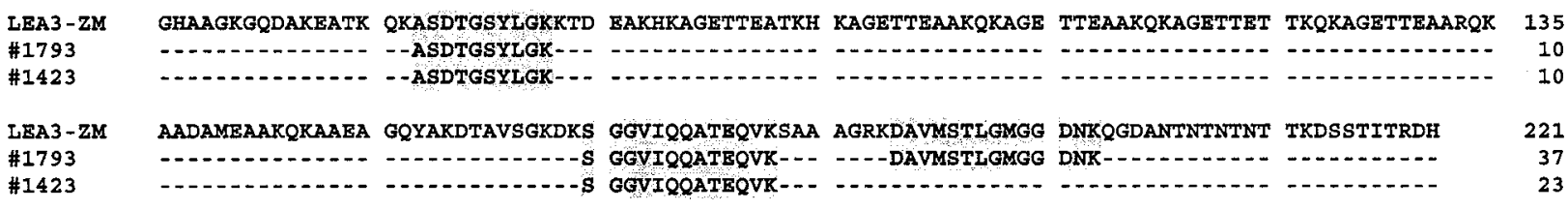

$\mathbf{B}$

LEA14-GH ----MSOLLEKAK DFVVDKVANIKKPEA SVSDVDLKHVSRECV EYGAKVSVSNPYSHS IPICEISYNFRSAGR GIASGTIPDPGSLKA LEA14-GM -.--MSQLLDKAK NYVAEKVTNMPKPEA SVTDVDFKRVSRDSV EYLAKVSVSNPYSTP IPICEIKYSLKSAGK EIASGTIPDPGSLKA AAC62908 EEKASVISSLLDKAK GFFAEKLANIPTPEA TVDDVDFKGVTRDGV DYHAKVSVKNPYSQS IPICQISYILKSATR TIASGTIPDPGSLVG AW331170 ERSVGLMAGLMDKAK GFVVEKVTQIPKPEA ALDHVSFRSISREGV ELHSHVDISNPYSHR IPICEITYTFKSAGK VIASGTMPDPGWIAA \#1868 AW566229 --NSAPGLMDKAK GFVVEKIAHIPKPEA TLDGVTFKGLSRECI TLHSSVWVSNPYDHR IPICEVTYTLRCAGK EVASGTMPDPGWIAA

84

84 99 135 15 86

LEAI4-GE SDTTMLDVPVKVPYN ILVSLVKDIGADWDI DYELELGLTIDLPIV GNFTIPLSQKGEIKL PTLSDIF-....- -... LEAI4-GM SDTTMLDVPVKVPHS ILLSLAKDIGADWDI DYQLDLGLVIDLPVI GNFTIPLSQKGEIKL PTLSDMFA-...- -..AAC62908 SGTTVLDVPVKVAYS IAVSLMRDMCTDWDI DYQLDIGLTFDIPVV GDITIPVSTQGEIKL PSLRDFF-....- -..AW331170 SGSTKLDLPVKVRYD FIVSLMKDLGGDWDI DYMLEVLTVDLPAI GAFTIPLTTEGEIKL PTFRDLLSKQFRCLV YESIC \#1868 AW566229 SGSTALEIPAKVPYD FLVSLVRDVGRDWDI DYELQVGLTVDIPIV GNFTIPLSTSGEFKL PTLKDLF_.... ...

Fig. 5. Amino acid sequence alignments of A, maize group 3 late embryogenesis abundant protein with peptide sequences of spots 1793 and 1423 and $\mathbf{B}$, group

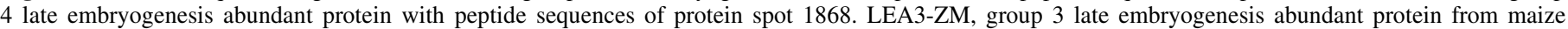

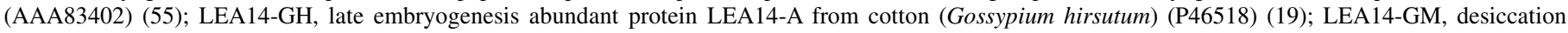

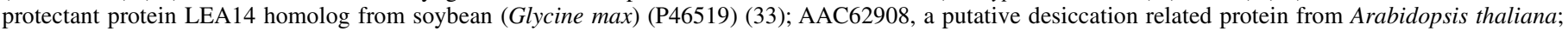
AW331170, and AW566229 are two maize expressed sequence tags. The conserved amino acid residues are highlighted. 
demonstrated an ALD profile similar to that of susceptible genotypes.

Data for Mp420, T115, and GT-MAS:gk suggests that higher constitutive levels of ALD activity may be important to aflatoxin resistance, in agreement with previous investigations $(12,22)$. Since an aldose reductase homologous gene is present in Aspergillus (23), the relatively high aldose reductase activities in infected susceptible kernels may even represent a combination of both plant and fungal ALD activity. A high level of expression of the fungal ALD gene inside of susceptible kernels (compared to resistant kernels) might be expected, since higher levels of fungal growth are normally observed in susceptible seeds. The different ALD activity responses between $\mathrm{Mp} 313 \mathrm{E}$ and the other resistant lines are not clearly understood. However, aflatoxin resistance is a multigene-controlled trait $(17,51)$, therefore, the expression or impact of an individual gene on resistance in a specific genotype might require further investigation using molecular genetic or transformation tools.

It is interesting to point out that some of the identified spots, which are the same proteins based on peptide sequences, appeared in different positions in 2-D PAGE among maize genotypes (e.g., spots 1391, 1406 in Mp420; spot 1423 in Mp420 and spot 1786 in Mo17; and ALD spots). This means that certain unique spots on 2D gels may represent different isoforms of the same protein. Position shifts have been previously suggested to be primarily due to

TABLE 4. Comparison of aldose reductase activity and aflatoxin accumulation between kernels of resistant and susceptible maize genotypes

\begin{tabular}{lcccc}
\hline Genotype & Resistance ${ }^{\mathrm{x}}$ & $\begin{array}{c}\text { Aflatoxin } \\
\mathrm{B}_{1}(\mathrm{ppb})^{\mathrm{y}}\end{array}$ & $\begin{array}{c}\text { ALD activity } \\
\text { before } \\
\text { infection }^{\mathrm{z}}\end{array}$ & $\begin{array}{c}\text { ALD } \\
\text { activity after } \\
\text { infection }\end{array}$ \\
\hline G4666 & $\mathrm{S}$ & $337.0 \mathrm{a}$ & $52.9 \mathrm{e}$ & $137.2 \mathrm{a}$ \\
P3165 & $\mathrm{S}$ & $205.4 \mathrm{~b}$ & $68.8 \mathrm{~d}$ & $135.2 \mathrm{a}$ \\
B73 & $\mathrm{S}$ & $111.9 \mathrm{bc}$ & $93.9 \mathrm{c}$ & $53.5 \mathrm{c}$ \\
Mp420 & $\mathrm{R}$ & $99.1 \mathrm{c}$ & $98.3 \mathrm{c}$ & $45.1 \mathrm{~d}$ \\
Mp313E & $\mathrm{R}$ & $118.9 \mathrm{bc}$ & $47.5 \mathrm{e}$ & $133.6 \mathrm{a}$ \\
T115 & $\mathrm{R}$ & $89.9 \mathrm{c}$ & $188.1 \mathrm{a}$ & $128.8 \mathrm{~b}$ \\
GT-MAS:gk & $\mathrm{R}$ & $77.8 \mathrm{c}$ & $108.4 \mathrm{~b}$ & $38.1 \mathrm{e}$ \\
\hline
\end{tabular}

${ }^{\mathrm{x}} \mathrm{R}=$ resistant, $\mathrm{S}=$ susceptible.

y Within columns, values followed by the same letter did not differ significantly by Duncan's multiple range test; ppb, parts per billion or equivalent to ng per g kernel.

$\mathrm{z}$ The unit of aldose reductase activity is nano mole NADPH per min per milligram kernel protein.

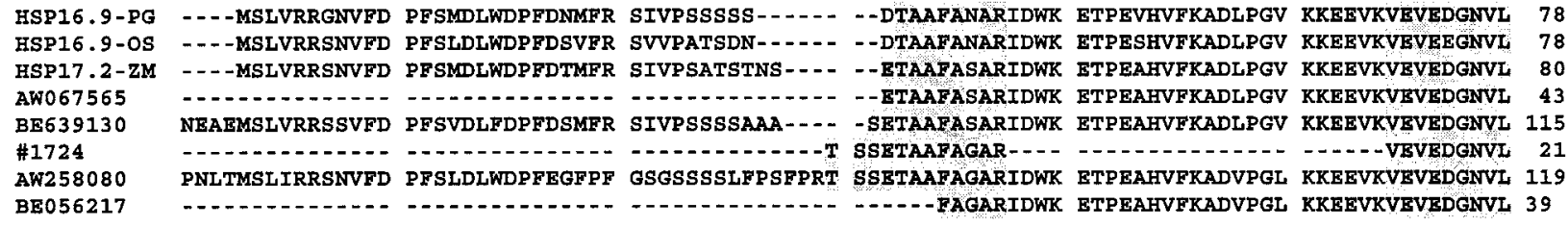

HSP16.9-PG VISGQRSK-EKEDKN DRWHRVERSSGQFVR RFRLPEDAKTDQVNA GLENGVLTVTVPKAE GKKPEVKAIEISG HSP16.9-OS VISGORSK-EKEDKN DKWHRVERSSGOFMR RFRLPENAKVDQVKA GLENGVLTVTVPKAE VKKPEVKAIEISG HSP17.2-ZM VISGORSR-EKEDKD DKWHRVERSSGOFIR RFRLPDDAKVDQVKA GLENGVLTVTVPKAE EKKPEVKAIEISG AW067565 LISGQRSR-EKEDKG DKWHRVERSSGQFVR RFRIPENAKTEEVRA ALENGVLTVIVPKAE VKKPEVKSIQISG BE639130 LISGQRSRXRRRTXG DKWHRVERSSGQFVR RFRLPENAKTEEVRA ALENGVLTVTVPKAE VKKPEVKSIQIS-

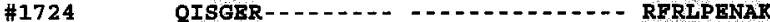

AW258080 QISGERNK-EQEEKT DTWHRVERSSGRFLR RFRLPENAKTEQIRA AMENGVLTVTVPKED VKKPEVK-..-BE056217 QISGERNK-EQEEKT DTWHRVERSSGRFLR RFRLPENAKTEQITA AMENGVLTVTVPKED AKKPEVKSIQISG

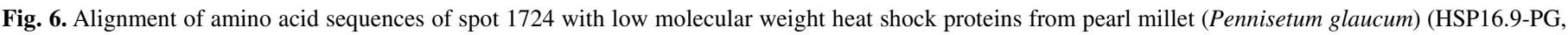

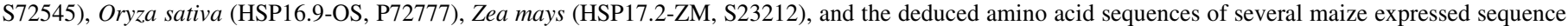
tags (AW067565, AW258080, BE639130, and BE056217). The conserved amino acid residues are highlighted.

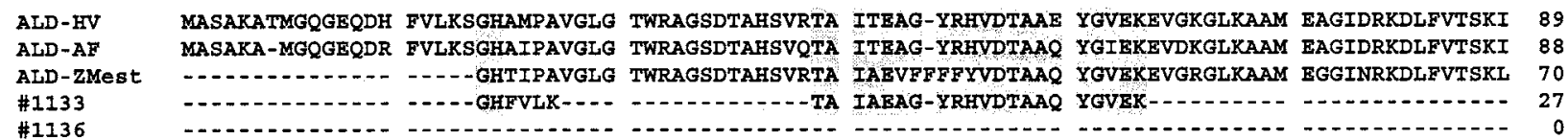

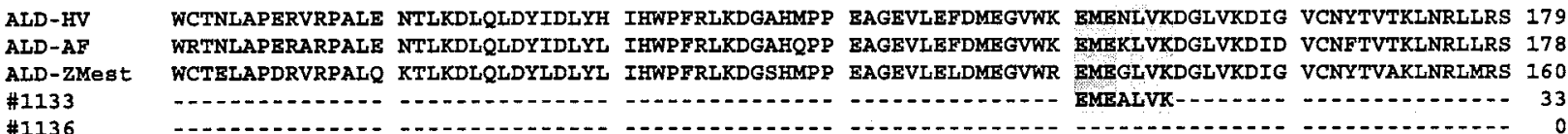

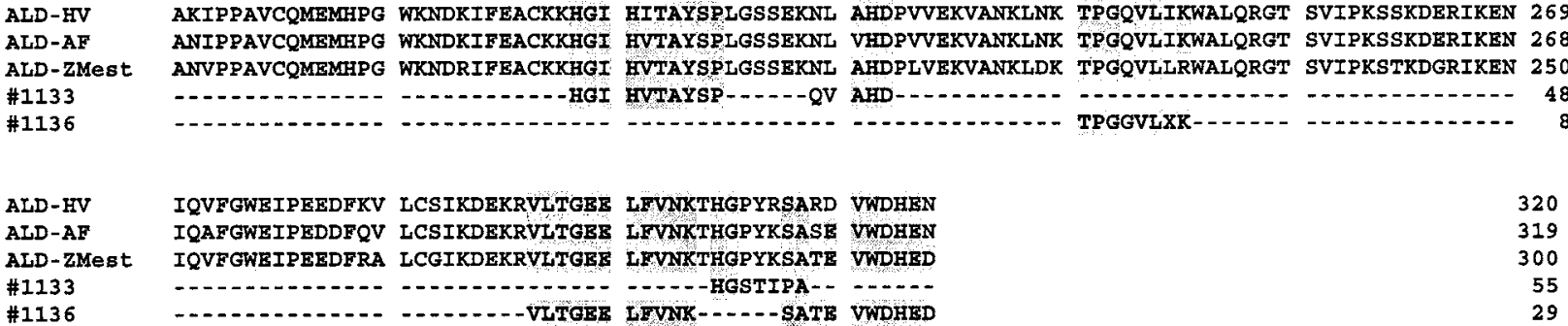

Fig. 7. Amino acid sequence alignment of peptides from spots 1133 and 1136 with amino acid sequences of aldose reductase from barley (Hordeum vulgare) (ALD-HV, P23901), wild oat (Avena fatua) (ALD-AF, S61421), and the merged amino acid sequences (ALD-ZMest) deduced from two maize expressed sequence tags (AW261223 and AW231664). The conserved amino acid residues are highlighted. " $\mathrm{X}$ " in the peptide sequences of spot 1136 indicates a modified unknown amino acid residue. 
the polymorphism of structural genes (49). Therefore, one advantage of using 2-D PAGE to study a trait is that it may allow the identification of the corresponding gene when a cDNA probe detects several loci in genetic mapping (49). These isoform variations (due to different pI and/or MW) among genotypes, in addition to variations in the level of protein expression, may also contribute to different levels of enzymatic or biological activities of the same protein under the same biological conditions.

The identification of stress-related proteins uniquely present or up-regulated in kernel embryos of resistant maize lines, Mp420 and Mp313E, may signal a breakthrough in understanding natural resistance. Heretofore, most kernel proteins identified and associated with resistance to A. flavus/aflatoxin production have had antifungal activities. Results of the present study indicate that the necessary requirements for developing commercially useful, yet aflatoxin-resistant maize lines may also include a high level of expression of stress-related proteins. Future investigations of these proteins, including genetic mapping of Mp420- and Mp313Ederived populations, plant transformation using corresponding genes, and marker-assisted breeding, should provide greater clarity as to their significance.

\section{ACKNOWLEDGMENTS}

We thank C. Ambrogio, D. Hadrick, and J. Veal for technical assistance; and D. Bhatnagar for critical reviewing of the manuscript.

\section{LITERATURE CITED}

1. Altschul, S. F., Madden, T. L., Schäffer, A. A., Zhang, J.-H., Zhang, Z., Miller, W., and Lipman, D. J. 1997. Gapped BLAST and PSI-BLAST: A new generation of protein database search programs. Nucleic Acids Res. 25:3389-3402.

2. Bartels, D., Engelhardt, K., Roncarati, R., Schneider, K., Rotter, M., and Salamini, F. 1991. An ABA and GA modulated gene expressed in the barley embryo encodes an aldose reductase related protein. EMBO J. 10:1037-1043.

3. Belanger, F. C., and Kriz, A. L. 1989. Molecular characterization of the major maize embryo globulin encoded by the Glb1 gene. Plant Physiol. 91:636-643.

4. Belanger, F. C., and Kriz, A. L. 1991. Molecular basis for allelic polymorphism of the maize Globulin-1 gene. Genetics 129:863-872.

5. Bradford, M. M. 1976. A rapid and sensitive method for the quantitation of microgram quantities of protein utilizing the principle of protein-dye binding. Anal. Biochem. 72:248-254.

6. Brown, R. L., Chen, Z.-Y., Cleveland, T. E., and Russin, J. S. 1999. Advances in the development of host resistance in corn to aflatoxin contamination by Aspergillus flavus. Phytopathology 89:113-117.

7. Brown, R. L., Chen, Z.-Y., Menkir, A., Cleveland, T. E., Cardwell, K., Kling, J., and White, D. G. 2001. Resistance to aflatoxin accumulation in kernels of maize inbreds selected for ear rot resistance in West and Central Africa. J. Food Prot. 64:396-400.

8. Brown, R. L., Cleveland, T. E., Payne, G. A., Woloshuk, C. P., Campbell, K. W., and White, D. G. 1995. Determination of resistance to aflatoxin production in maize kernels and detection of fungal colonization using an Aspergillus flavus transformant expressing Escherichia coli $\beta$ glucuronidase. Phytopathology 85:983-989.

9. Brown, R. L., Cotty, P. J., Cleveland, T. E., and Widstrom, N. W. 1993. Living maize embryo influences accumulation of aflatoxin in maize kernels. J. Food Prot. 56:967-971.

10. Campbell, K. W., and White, D. G. 1995. Evaluation of corn genotypes for resistance to Aspergillus ear rot, kernel infection, and aflatoxin production. Plant Dis. 79:1039-1045.

11. Cavan, G. P., Skoet, K., Stevens, M. J., and Howarth, C. J. 1996. Sequence announcement. Plant Mol. Biol. 30:1076-1076.

12. Chen, Z.-Y., Brown, R. L., Cleveland, T. E., Damann, K. E., and Russin, J. S. 2001. Comparison of constitutive and inducible maize kernel proteins of genotypes resistant or susceptible to aflatoxin production. J. Food Prot. 64:1785-1791.

13. Chen, Z.-Y., Brown, R. L., Lax, A. R., Cleveland, T. E., and Russin, J. S. 1999. Inhibition of plant-pathogenic fungi by a corn trypsin inhibitor overexpressed in Escherichia coli. Appl. Environ. Microbiol. 65:13201324.

14. Chen, Z.-Y., Brown, R. L., Lax, A. R., Guo, B. Z., Cleveland, T. E., and Russin, J. S. 1998. Resistance to Aspergillus flavus in corn kernels is associated with a $14 \mathrm{kDa}$ protein. Phytopathology 88:276-281.

15. Chen, Z.-Y., Brown, R. L., Russin, J. S., Lax, A. R., and Cleveland, T. E. 1999. A corn trypsin inhibitor with antifungal activity inhibits Aspergillus flavus $\alpha$-amylase. Phytopathology 89:902-907.

16. Chen, Z.-Y., Cleveland, T. E., Brown, R. L., Bhatnagar, D., Cary, J. W., and Rajasekaran, K. Corn as a source of antifungal genes for genetic engineering of crops for resistance to aflatoxin contamination. Pages 131-150 in: Crop Biotechnology, ACS Symposium Series No. 829. K. Rajasekaran, J. W. Finley, and T. J. Jacks, eds. American Chemical Society, Washington, DC.

17. Davis, G. L., and Williams, W. P. 1999. QTL for aflatoxin reduction in maize. Maize Genetics Conf. 41:22.

18. Diener, U. L., Cole, R. J., Sanders, T. H., Payne, G. A., Lee, L. S., and Klich, M. A. 1987. Epidemiology of aflatoxin formation by Aspergillus flavus. Annu. Rev. Phytopathol. 25:249-270.

19. Galau, G. A., Wang, H. Y., and Hughes, D. W. 1993. Cotton Lea5 and Lea14 encode atypical late embryogenesis-abundant proteins. Plant Physiol. 101:695-696.

20. Garay-Arroyo, A., Colmenero-Flores, J. M., Garciarrubio, A., and Covarrubias, A. A. 2000. Highly hydrophilic proteins in prokaryotes and eukaryotes are common during conditions of water deficit. J. Biol. Chem. 275:5668-5674.

21. Görg, A., Boguth, G., Obermaier, C., and Weiss, W. 1998. Two-dimensional electrophoresis of proteins in a immoilized $\mathrm{pH}$ 4-12 gradient. Electrophoresis 19:1516-1519.

22. Guo, B. Z., Russin, J. S., Cleveland, T. E., Brown, R. L., and Widstrom, N. W. 1996. Resistance to aflatoxin contamination in corn as influenced by relative humidity and kernel germination. J. Food Prot. 59:276-281.

23. Hasper, A. A., Visser, J., and de Graaff, L. H. 2000. The Aspergillus niger transcriptional activator $\mathrm{X} \operatorname{lnR}$, which is involved in the degradation of the polysaccharides xylan and cellulose, also regulates D-xylose reductase gene expression. Mol. Microbiol. 36:193-200.

24. Hendrich, J. P., and Hartl, F. U. 1993. Molecular chaperone functions of heat shock proteins. Annu. Rev. Biochem. 62:349-384.

25. Jacob, U., Gaestel, M., Engel, K., and Buchner, J. 1993. Small heat shock proteins are molecular chaperones. J. Biol. Chem. 268:1517-1520.

26. Jones, R. K., Duncan, H. E., and Hamilton, P. B. 1981. Planting date, harvest date, and irrigation effects on infection and aflatoxin production by Aspergillus flavus in field corn. Phytopathology 71:810-816.

27. Kawasaki, N., Tanimoto, T., and Tanaka, A. 1989. Characterization of aldose reductase and aldehyde reductase from rat testis. Biochim. Biophys. Acta 996:30-36.

28. Keller, N. P., Butchko, R. A. E., Sarr, B., and Phillips, T. D. 1994. A visual pattern of mycotoxin production in maize kernels by Aspergillus spp. Phytopathology 84:483-488.

29. Kiyosue, T., Yamaguchi-Shinozaki, K., and Shinozaki, K. 1994. Cloning of cDNAs for genes that are early responsive to dehydration stress (ERDs) in Arabidopsis thaliana L.: Identification of three ERDs as HSP cognate genes. Plant Mol. Biol. 25:791-798.

30. Kriz, A. L. 1989. Characterization of embryo globulins encoded by the maize Glb genes. Biochem. Genet. 27:239-251.

31. Lee, S. P., and Chen, T. H. H. 1993. Molecular cloning of abscisic acidresponsive mRNAs expressed during the induction of freezing tolerance in bromegrass (Bromus inermis Leyss) suspension culture. Plant Physiol. 101:1089-1096.

32. Li, B., and Foley, M. E. 1995. Cloning and characterization of differentially expressed genes in imbibed dormant and afterripened Avena fatua embryos. Plant Mol. Biol. 29:823-831.

33. Maitra, N., and Cushman, J. C. 1994. Isolation and characterization of a drought-induced soybean cDNA encoding a D95 family late-embryogenesis-abundant protein. Plant Physiol. 106:805-806.

34. Nichols, T. E., Jr. 1983. Economic impact of aflatoxin in corn. South. Coop. Ser. Bull. 279:67-71.

35. Oberschall, A., Deak, M., Torok, K., Sass, L., Vass, I., Kovacs, I., Feher, A., Dudits, D., and Horvath, G. V. 2000. A novel aldose/aldehyde reductase protects transgenic plants against lipid peroxidation under chemical and drought stresses. Plant J. 24:437-446.

36. Payne, G. A. 1998. Process of contamination by aflatoxin-producing fungi and their impact on crops. Pages 279-306 in: Mycotoxins in Agriculture and Food Safety. K. K. Sinha and D. Bhatnagar, eds. Marcel Dekker, New York.

37. Payne, G. A., Cassel, D. K., and Adkins, C. R. 1986. Reduction of aflatoxin contamination in corn due to irrigation and tillage. Phytopathology 76:679-684.

38. Picard, P., Bourgoin-Greneche, M., and Zivy, M. 1997. Potential of twodimensional electrophoresis in routine identification of closely related durum wheat lines. Electrophoresis 18:174-181.

39. Riccardi, F., Gazeau, P., de Vienne, D., and Zivy, M. 1998. Protein changes in response to progressive water deficit in maize: Quantitative 
variation and polypeptide identification. Plant Physiol. 117:1253-1263.

40. Roncarati, R., Salamini, F., and Bartels, D. 1995. An aldose reductase homologous gene from barley: Regulation and function. Plant J. 7:809822.

41. Sabehat, A., Lurie, S., and Weiss, D. 1998. Expression of small heatshock proteins at low temperatures. A possible role in protecting against chilling injuries. Plant Physiol. 117:651-658.

42. Santoni, V., Delarue, M., Caboche, M., and Bellini, C. 1997. A comparison of two-dimensional electrophoresis data with phenotypical traits in Arabidopsis leads to the identification of a mutant (cril) that accumulates cytokinins. Planta 202:62-69.

43. Scott, G. E., and Zummo, N. 1988. Sources of resistance in maize to kernel infection by Aspergillus flavus in the field. Crop Sci. 28:504-507.

44. Smart, M. G., Wicklow, D. T., and Caldwell, R. W. 1990. Pathogenesis in Aspergillus ear rot of maize: Light microscopy of fungal spread from wounds. Phytopathology 80:1287-1294.

45. Soto, A., Allona, I., Collada, C., Guevara, M. A., Casado, R., RodriguezCerezo, E., Aragoncillo, C., and Gomez, L. 1999. Heterologous expression of a plant small heat-shock protein enhances Escherichia coli viability under heat and cold stress. Plant Physiol. 120:521-528.

46. Sun, J. L., Nakagawa, H., Karita, S., Ohmiya, K., and Hattori, T. 1996. Rice embryo globulins: Amino-terminal amino acid sequences, cDNA cloning and expression. Plant Cell Physiol. 37:612-620.

47. Takahashi, R., Joshee, N., and Kitagawa, Y. 1994. Induction of chilling resistance by water stress, and cDNA sequence analysis and expression of water stress-regulated genes in rice. Plant Mol. Biol. 26:339-352.

48. Thomann, E. B., Sollinger, J., White, C., and Rivin, C. J. 1992. Accumulation of group 3 late embryogenesis abundant proteins in Zea mays embryos. Plant Physiol. 99:607-614.

49. Touzet, P., Morin, C., Damerval, C., Le Guilloux, M., Zivy, M., and de Vienne, D. 1995. Characterizing allelic proteins for genome mapping in maize. Electrophoresis 16:1289-1294.

50. Tseng, T. S., Yeh, K. W., Yeh, C. H., Chang, F. C., Chen, Y. M., and Lin, C. Y. 1992. Two rice (Oryza sativa) full-length cDNA clones encoding low-molecular-weight heat-shock proteins. Plant Mol. Biol. 18:963-965.
51. Walker, R. D., and White, D. G. 2001. Inheritance of resistance to Aspergillus ear rot and aflatoxin production of corn from CI2. Plant Dis. 85:322-327.

52. Wallace, N. H., and Kriz, A. L. 1991. Nucleotide sequence of a cDNA clone corresponding to the maize Globulin-2 gene. Plant Physiol. 95: 973-975.

53. Wehmeyer, N., and Vierling, E. 2000. The expression of small heat shock proteins in seeds responds to discrete developmental signals and suggests a general protective role in desiccation tolerance. Plant Physiol. 122:1099-1108.

54. Westgate, M. E. 1994. Water status and development of the maize endosperm and embryo during drought. Crop Sci. 34:76-83.

55. White, C. N., and Rivin, C. J. 1995. Sequence and regulation of a late embryogenesis abundant group 3 protein of maize. Plant Physiol. 108: 1337-1338.

56. Widstrom, N. W., McMillian, W. W., and Wilson, D. M. 1987. Segregation for resistance to aflatoxin contamination among seeds on an ear of hybrid maize. Crop Sci. 27:961-963.

57. Windham, G. L., and Williams, W. P. 1999. Aflatoxin accumulation in commercial corn hybrids in 1998. Miss. Agric. For. Exp. Stn. Res. Rep. 22:8.

58. Windham, G. L., and Williams, W. P. 2002. Evaluation of corn inbreds and advanced breeding lines for resistance to aflatoxin contamination in the field. Plant Dis.86:232-234.

59. Woloshuk, C. P., Cavaletto, J. R., and Cleveland, T. E. 1997. Inducers of aflatoxin biosynthesis from colonized maize kernels are generated by an amylase activity from Aspergillus flavus. Phytopathology 87:164-169.

60. Xu, D., Duan, X., Wang, B., Hong, B., Ho, T. H. D., and Wu, R. 1996. Expression of a late embryogenesis abundant protein gene, HVA1, from barley confers tolerance to water deficit and salt stress in transgenic rice. Plant Physiol. 110:249-257.

61. Yeh, C. H., Chang, P. L., Yeh, K. W., Lin, W. C., Chen, Y. M., and Lin, C. Y. 1997. Expression of a gene encoding a 16.9-kDa heat-shock protein, Oshsp16.9, in Escherichia coli enhances thermotolerance. Proc. Natl. Acad. Sci. USA 94:10967-10972. 